\title{
Student-centered learning in an engineering course with project-integrated laboratory experiment
}

\author{
Jennifer Leijon*, Kjell Staffas, Cecilia Boström and Hans Bernhoff \\ Department of Electrical Engineering, Uppsala University, Sweden
}

\begin{abstract}
In this paper we discuss and present results from the pedagogical development of an advancedlevel undergraduate electrical engineering course at Uppsala University, where a new laboratory experiment was implemented. The implementation of the laboratory experiment seemed to result in improved student performance on written tests and a better overall success/pass rate when compared with previous years. The aim of this paper is to describe the course development and its outcome, with a focus on the individual engineering laboratory experiment. We conclude that unique student tasks, connected to realistic engineering problems, may increase the engagement and subject understanding of students.
\end{abstract}

Keywords: Electrical machines, problem-based learning, student-centered learning, laboratory experiment, engineering education, STEM

\section{INTRODUCTION}

The Rotating Electrical Machines ${ }^{1}$ course (REM), part of an electrical engineering program at Uppsala University, ${ }^{2}$ has suffered from low satisfaction levels among students. In addition, the course is known to have a high failure rate and is considered by students to be tough and the content difficult to understand. To come to terms with these problems, we implemented several changes to the course: video lectures, student-centered learning (SCL) during lessons, restructuring the course compendium, etc. The course was moved from the second to the third year of the engineering program to ensure, for example, that students have an adequate mathematical background to achieve the learning goals. Lastly, a new type of laboratory work (lab) was included, which is the focus of this paper. Besides effecting a higher success rate, from a pedagogical perspective we also wanted to improve the learning experience of our students. To achieve this, we proposed to better align the course with the teaching and learning vision of the university, ${ }^{3}$ supported by insights from educational research. The aim of this paper is to present the development of the REM course, with a focus on the new lab. It is structured as follows: a literature background is presented, thereafter, implementation of the lab in REM is described, followed by results, discussion, and conclusions.

http://www.uu.se/en/admissions/master/selma/kursplan/?kKod=1TE670 [Accessed: 2019-02-26]

https://www.teknat.uu.se/?languageId=1 [Accessed: 2019-02-26]

https://www.uu.se/en/about-uu/quality/learning/educational-development/programme-for-teachingand-learning/ [Accessed: 2020-03-17]

*Correspondence: jennifer.leijon@angstrom.uu.se

Artiklar och reflektioner är kollegialt granskade. Övriga bidragstyper granskas av redaktionen. Se https://hogreutbildning.se ISSN 2000-7558

(C2020 Jennifer Leijon, Kjell Staffas, Cecilia Boström and Hans Bernhoff. This is an Open Access article distributed under the terms of the Creative Commons Attribution-NonCommercial 4.0 International License (https://creativecommons.org/licenses/by-nc/4.0/), allowing third parties to share their work (copy, distribute, transmit) and to adapt it, under the condition that the authors are given credit, that the work is not used for commercial purposes, and that in the event of reuse or distribution, the terms of this license are made clear.

Citation: Leijon, J., Staffas, K., Boström, C. \& Bernhoff, H. (2020). "Student-centered learning in an engineering course with project-integrated laboratory experiment», Högre utbildning, 10(1), 57-62. https://doi.org/10.23865/hu.v10.2179 


\section{Jennifer Leijon et al.}

In a recent study, a group of engineering students in Turkey were asked about science literacy. Laboratory work was seen as an important part (Şadoğlu, 20I8), which we agree with. As presented in that paper, the students believed that labs develop practical skills, put theory into practice and increase the overall learning. New demands on engineers in industry and academia may affect which types of labs that are included in engineering programs. Apart from good technical skills, future engineers are increasingly encouraged to gain generic skills as well (Leijon \& Boström, 2019). The necessity of adapting engineering education to new times and situations calls for an open mind and innovative solutions. Different types of labs have been designed along with new ways of evaluating learning outcomes from the labs. Remote labs, i.e. virtual labs, have been proposed, highlighting several benefits in terms of availability, safety, and accessibility (Marques et al., 20I4). Recent research describes, for example, virtual teaching of electric circuit labs (Saleheen, Wang, Picone, Butz, \& Won, 2018) and the incorporation of sustainability concerns in labs using case studies (Luster-Teasley, 2017). These studies show opportunities to think outside the box when it comes to labs. Also, benefits in terms of accessibility and activity could be reaped if the students are not in need of a physical lab to do all parts of the laboratory work.

The constructivist perspective on learning (Taber, 2000) is widely accepted throughout higher education. As a consequence, more student-active methods with a basis in project and problem-based learning (PBL) have been developed and established (Neville \& Norman, 2007). It is suggested that PBL leads to positive results when testing students' understanding of principles that link concepts (Gijbels, Dochy, Van Den Bossche, \& Segers, 2005). To increase student learning, research implies that active and student-centered teaching methods are highly beneficial (Prince $\&$ Felder, 2006). These ideas have been implemented in engineering education, for example, combining different pedagogical strategies (Staffas, 20I7). We have been inspired by these studies. With a basis in this research, we implemented problem-based assignments in the REM course related to realistic problems that were unique for each student. The individual assignment, with different input variables, is directly introduced in the teaching process and becomes the common denominator between lecturing, diagnostic tests, problem-solving, etc. Most of the assignments are similar and so the students benefit from collaboration. The hypothesis is that the individual labs can increase conceptual understanding and include variation and student activity in the classroom.

\section{THE NEW LAB IN THE REM COURSE}

We implemented a new lab in the REM course in 2019. Each student was assigned an individual type of rotating machine with a specific number of poles in the rotor and number of phases. They received a stator steel sheet, see Figure I(a), and cables for stator winding. The task was to wind their machine according to theory before a lab session. Before coming to the lab session, students were required to perform basic calculations and make diagrams of their windings. The students had to complete their winding before attending the lab session. The experiment then involved students testing their assembly with a hand-driven rotor equipped with surface-mounted magnets. This was, in turn, connected to an oscilloscope and a computer, see Figure I(b). As the rotor spun, a unique output in the form of a sinusoidally-varying voltage was recorded, which could be further analyzed at home. The students would then investigate what happened when spinning the rotor faster, increasing the number of poles or phases, etc. Discussions on how large machines are created would come up and such discussions could continue, for example, at an industry study visit. 


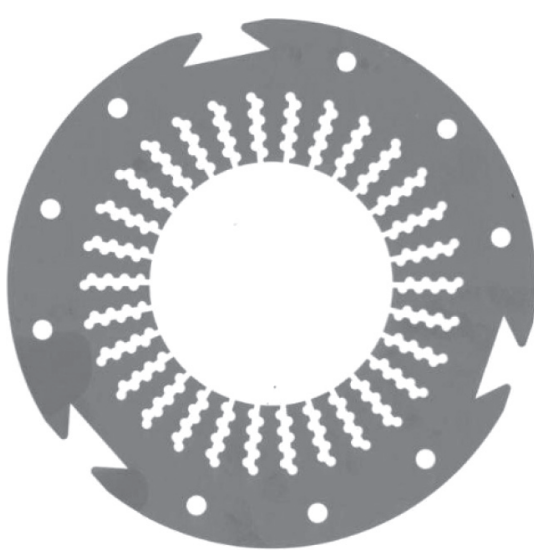

(a)

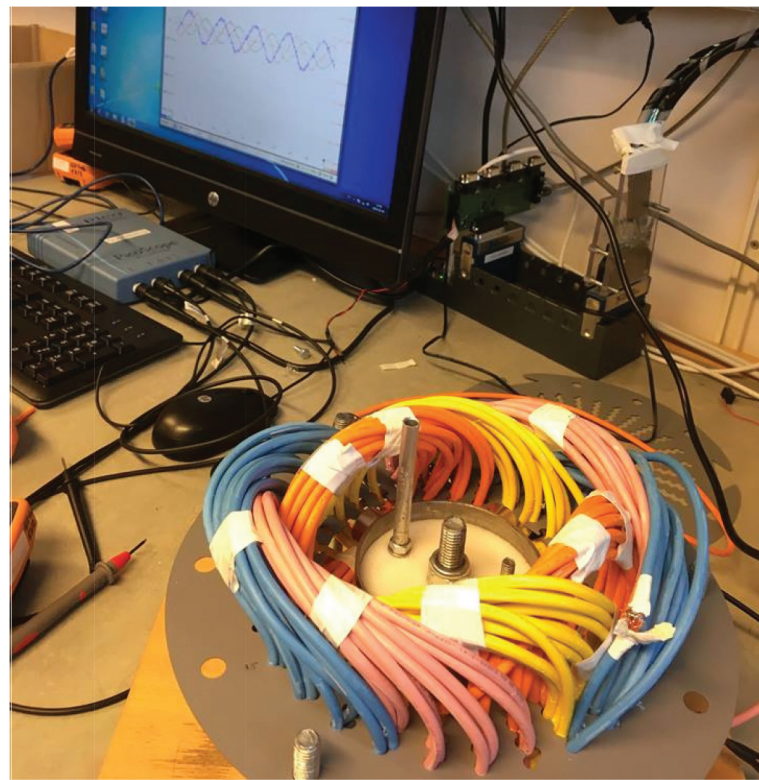

(b)

Figure I. (a) Stator sheet given to the students. (b) A student solution in the lab

\section{RESULTS}

The results presented are based on midterm test results, final exam results, and final course evaluations for the REM course given in 2017 (before course development) and in 2019 (after course development), as well as on the results from a midterm course evaluation from 2019.

The students could get a maximum of 3 credits on the midterm test of the REM course. In 2017, the mean credit on this test was 0.8. In 20I9, the mean credit was 2.25. In 20I7, only about a quarter of the students passed the final exams, whereas about two-thirds of the students passed them in 20I9. All evaluation questions were asked in Swedish, and so the responses shown below have been translated into English. The midterm course evaluation from 2019 is presented in Table I. The number of students answering this questionnaire was only I3, due to a small class. The students were asked to freely comment on the lab in the middle of the course, examples of which are presented here: "I think that it is a rather fun lab, a good complement to the learning," "A bit hard as the divided windings are not mentioned in the compendium," "Fun, but a bit unclear. It is hard to do it well," "Valuable. Gives more of a practical understanding," "Good lab, well connected to the course."

Table I. Midterm course evaluation

\begin{tabular}{lc}
\hline Question & Answer \\
\hline At which level would you describe the course? On a scale from I (very easy) to 5 (very hard) & Mean value: 4.15 \\
Would you recommend the course to other students? & 6I.5\% yes \\
Do you think that you learn more from this type of course than the more traditional ones? & IOO\% yes \\
Did you collaborate more than you usually do with your classmates in this course? & $84.6 \%$ yes \\
\hline
\end{tabular}




\section{Jennifer Leijon et al.}

Results from the final summative course evaluation are presented in Table 2. Some free comments on the course were as follows: "A big plus for the design of teaching," "The lab was a bit unnecessary," "Good work!". The students also answered a question on what was particularly good about this course: "The will to make a good course and the work with forms of teaching," "It was fun with a practical assignment among the theory but maybe it took a bit too much time on the whole," "The design of the teaching [was great]."

For the teachers, it took time to prepare and adjust the content for SCL. With regards to the lab, it was necessary to plan and buy equipment in advance. However, two teachers managed both the new lab and other pedagogical improvements to the course. Moreover, as the students were encouraged to work more actively and independently, this decreased the workload of the teachers, suggesting the course development could save time over the longer term.

Table 2. Final summative course evaluation

\begin{tabular}{|c|c|}
\hline Question & Answer, mean value \\
\hline $\begin{array}{l}\text { How was the lab? } \\
\text { I (not valuable) to } 5 \text { (very valuable) }\end{array}$ & 3.39 \\
\hline $\begin{array}{l}\text { The course has increased my problem-solving skills: } \\
\text { I (don't agree at all) to } 5 \text { (agree fully) }\end{array}$ & 3 \\
\hline $\begin{array}{l}\text { My general opinion of the course is: } \\
\text { I (very poor) to } 5 \text { (very good) }\end{array}$ & 3.75 \\
\hline $\begin{array}{l}\text { The level of the course was: } \\
\text { I (very easy) to } 5 \text { (very hard) }\end{array}$ & 3.64 \\
\hline
\end{tabular}

\section{DISCUSSION AND CONCLUSIONS}

Scientific literature highlights that labs can be an important part of engineering education to enhance the practical skills, understanding, and active engagement of students. We see that labs at university level can be designed to bridge the gap between academia and industry, as well as to introduce a greater variation in learning activities. Recent research investigates how the labs can be improved, suggesting that there is a wide interest in lab development. This may reflect a slight change in the necessary skill set of an engineer and new challenges in society. Looking at Table I, the improved REM course is regarded as being rather hard (midterm). Nonetheless, at this stage of the course, more than half of all students recommend it. All students agree that they learn more from this new type of course than from traditional courses. It is noteworthy that $84.6 \%$ of the students experience that they collaborated more with their classmates than in other courses (Table I). We can perhaps describe this as peer learning, where the students benefit from each other in their understanding. Reducing the importance of teachers may empower students' free and deep learning, as well as improve their collaboration with fellow classmates. Peer learning through individual-based exercises or engineering labs thereby presents an interesting avenue for future research. Comparing Table I and 2, the students thought the course was easier at the end than at midterm. We also see that the students were neither very satisfied nor dissatisfied with the lab and overall course. Some students were confused about the lab while others appreciated it. Many more students passed the exam after the course development than before. We have not yet fully investigated the main reason for this. However, we expect that better utilization of relevant studies and guidelines on pedagogy is a good strategy for improving student results. The lab encouraged students to study both inside and outside the classroom, and the lab relates well to the course's theory. The course development was time-consuming for the two teachers, but 
manageable. Although the students collaborated, the focus of the project was not on the development of teamworking skills, but rather to understand electric system design. Each student requires their own set of experimental equipment, which may be costly. In summary, although the new lab may not have led to improvements in student grades all by itself, the considerable improvements in both student feedback and course outcomes suggests it may be interesting to both further investigate and work on developing the ideas of individual labs to strengthen the activity and learning of engineering students.

\section{ACKNOWLEDGEMENTS}

TUFF (pedagogic fund, Uppsala University), the Swedish Research Council VR grant number: 2015-03126, and STandUP for Energy. We would like to thank all reviewers of the manuscript.

\section{ABOUT THE AUTHORS}

Jennifer Leijon is an engineer and $\mathrm{PhD}$ student working at the Division of Electricity, Department of Electrical Engineering, Uppsala University, focusing on wave-powered desalination. She is interested in pedagogical development and discipline-based educational research. One of the teachers in the Rotating Electrical Machines course, she aims to support the students in their own learning.

Kjell Staffas is a senior lecturer in electronics, specializing in didactics, at Signals and Systems at the Department of Electrical Engineering, Uppsala University. His research interests include motivation and learning environments towards problem and project-based learning. $\mathrm{He}$ is a teacher in electronics and automation systems, pedagogical assessor and Distinguished University Teacher.

Cecilia Boström is a senior lecturer at the Division of Electricity, Department of Electrical Engineering, Uppsala University. Her research areas are electrical systems and grid connection of renewable energy sources. With an interest in pedagogical development, she has taught several electrical engineering courses and supervised $\mathrm{PhD}$ students.

Hans Bernhoff is a professor at the Division of Electricity, Department of Electrical Engineering, Uppsala University, with research on high performance electrical systems. He is one of the teachers in the Rotating Electrical Machines course, focusing on student-centered learning. $\mathrm{He}$ has taught several electrical engineering courses and supervised PhD students.

\section{REFERENCES}

Gijbels, D., Dochy, F., Van Den Bossche, P., \& Segers, M. (2005). Effects of problem-based learning: A meta-analysis from the angle of assessment. Review of Educational Research, 75(1), 27-61. https://doi. org/10.3102/00346543075001027

Leijon, J., \& Boström, C. (2019). Lärarens arbete mot utveckling av generiska färdigheter och variation i teknikvetenskaplig utbildning genom relationsskapande åtgärder. Högre Utbildning, 9(1), 85-97. https://doi.org/10.23865/hu.v9.1452

Luster-Teasley, S.-L. S. W. R. (2017). Case studies in sustainability used in an introductory laboratory course to enhance laboratory instruction. Journal of STEM Education: Innovations and Research, 18(2), $30-39$.

Marques, M. A., Viegas, M. C., Costa-Lobo, M. C., Fidalgo, A. V., Alves, G. R., Rocha, J. S., \& Gustavsson, I. (2014). How remote labs impact on course outcomes: Various practices using VISIR. IEEE Transactions on Education, 57(3), 151-159. https://doi.org/10.1109/TE.2013.2284156

Neville, A. J., \& Norman, G. R. (2007). PBL in the undergraduate MD Program at McMaster University: Three iterations in three decades. Academic Medicine, 82(4), 370-374. 


\section{Jennifer Leijon et al.}

Prince, M. J., \& Felder, R. M. (2006). Inductive teaching and learning methods: Definitions, comparisons, and research bases. Journal of Engineering Education, 95(2), 123-138. https://doi. org/10.1002/j.2168-9830.2006.tb00884.x

Şadoğlu, G. P. (2018). Engineering students' opinions on science literacy. Universal Journal of Educational Research, 6(8), 1819-1830. https://doi.org/10.13189/ujer.2018.060827

Saleheen, F., Wang, Z., Picone, J., Butz, B. P., \& Won, C. H. (2018). Efficacy of a virtual teaching assistant in an open laboratory environment for electric circuits. Advances in Engineering Education, 6(3), 1-27.

Staffas, K. (2017). Developing requisite motivation in engineering studies: A study on a master and bachelor program in electronic engineering at Uppsala University. Aalborg University.

Taber, K. S. (2000). Chemistry lessons for universities?: A review of constructivist ideas. University Chemistry Education, 4(2), 63-72. 